\title{
Two new records of Pseudis tocantins Caramaschi and Cruz 1998 (Anura, Pseudidae) in central Brazil
}

\author{
Reuber A. Brandão ${ }^{1,2}$, Guarino R. Colli ${ }^{1}$, Ayrton K. Peres Jr. ${ }^{1}$, and Tarcísio Lyra Abreu ${ }^{1}$ \\ 1 Departamento de Zoologia, Universidade de Brasília, 70910-900, Brasília, DF, Brazil. E-mail: \\ reuberbrandao@yahoo.com.br. \\ 2 Coordenação de Assuntos Fundiários (DICRI), Diretoria de Ecossistemas (DIREC), Instituto Brasileiro do Meio \\ Ambiente (IBAMA), Avenida L4 Norte, 70910-900, Brasília, DF, Brazil.
}

Keywords: Anura, Pseudidae, Pseudis tocantins, geographical distribution, central Brazil.

Pseudis tocantins was described by Caramaschi and Cruz (1998) based in individuals from the municipality of Porto Nacional, state of Tocantins, collected in 1947. At present, this species is known only from its type locality (Caramaschi and Cruz 1998, Frost 2002). Along the years 1999 and 2001, $P$. tocantins was observed several times on large and vegetated permanent ponds in the Tocantins river valley, between the cities of Porto Nacional and Palmas (Brandão and Peres Jr. 2001). However, this area was flooded by the reservoir of the Luis Eduardo Magalhães hydroelectric dam, in 2002. The formation of the lake, with 62.000 ha, destroyed the habitats used by $P$. tocantins, and probably causing its local extinction (i.e. the type population loose) (Brandão and Peres Jr. 2001).

Herein, we present two new records of $P$. tocantins from states of Mato Grosso and Goiás. The species identifications were confirmed comparing the animals with topotypes and with the original description. All collected animals were deposited at Coleção Herpetológica da Universidade de Brasília (CHUNB).

Received 4 March 2003

Accepted 29 May 2003

Distributed 31 October 2003

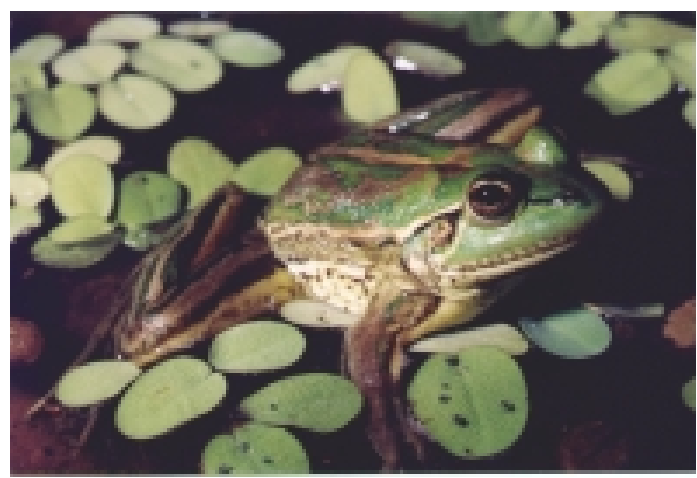

Figure 1 - Adult male of Pseudis tocantins (CHUNB 30355) from Britânia, state of Goiás.

The first record was from two individuals collected by G. R. Colli, G. Vieira, and A. K. Peres Jr. at Bananal Island National Park, Municipality of Santa Terezinha, state of Mato Grosso, in 19 April 1999 (10²8'12"S, $50^{\circ} 28^{\prime} 48^{\prime \prime} \mathrm{W}$; CHUNB 10369 - 10370). The second record was from three individuals collected by R. A. Brandão and T. L. Abreu in Municipality of Britânia, state of Goiás, in 8 February 2003 (15¹4'34”S, 51 $10^{\circ} 44^{\prime \prime} \mathrm{W}$; CHUNB 30355-30357; Figure 1).

The record of Pseudis tocantins at Santa Terezinha, in the Araguaia river, extends the 
species knowing distribution about $230 \mathrm{~km}$ to the west from the type locality (Porto Nacional). Britânia is also located in the Araguaia river valley, about $550 \mathrm{~km}$ south from the Santa Terezinha record, and is $590 \mathrm{~km}$ from the type locality. To our knowledge, $P$. tocantins occurs on large and vegetated ponds at seasonal flooded plains on the Tocantins/Araguaia river basin. As the Luis Eduardo Magalhães hydroelectric dam destroyed the original range of distribution of this species, these new records are important for show that the species are not extinct. This species, however, needs special attention, due to its habitat requirements and the large number of hydroelectric dams planned for the Araguaia and Tocantins rivers.

\section{References}

Brandão, R. A. and A. K. Peres Jr. 2001. Levantamento da herpetofauna na área de influência do Aproveitamento Hidroelétrico da UHE Luís Eduardo Magalhães (Palmas, TO). Humanitas 3:35-50.

Caramaschi, U. and C. A. G. Cruz. 1998. Notas taxonômicas sobre Pseudis fusca Garman e $P$. bolbodactyla A. Lutz, com descrição de uma nova espécie correlata (Anura: Pseudidae). Revista Brasileira de Zoologia 15:929-944.

Frost, D. R. (ed.). 2002. Amphibian Species of the World - an on line reference. URL: http://research.amnh.org/ herpetology/amphibia/index.html. Captured on 2 February 2003. 